\title{
REKLAMA RELIGIJNA JAKO PRZEKAZ PERSWAZYJNY Z ELEMENTAMI SACRUM
}

Historia reklamy jako narzędzia informacji i formy perswazji ma już swoją bogatą tradycję. Coraz częściej zagadnienie reklamy pojawia się w teologii zwłaszcza w teologii środków społecznego przekazu, bowiem to reklama stała się w ostatnim zwłaszcza okresie, szczególnym narzędziem w rękach Kościoła katolickiego, który przez długi czas pozostawał bardzo sceptycznie nastawiony do tego rodzaju komunikacji z szerokim odbiorcą. Odbiorcą ze swej natury anonimowym, heterogenicznym i rozproszonym.

Coraz częściej piszą o reklamie religijnej, czy też „reklamie Kościoła”, „reklamie wiary”, „bożej reklamie”, teolodzy¹. Większość z nich uważa reklamę religijną, idąc jakby za Dariuszem Karłowiczem, który o reklamie społecznej pisze jako o sztuce godziwej perswazji: narzędziu, którego jeżykiem próbuje się opowiedzieć historię, że Chrystus zmartwychwstał ${ }^{2}$, za rodzaj reklamy społecznej.

Definicyjnie reklama uważana jest za działanie perswazyjne. „Reklama jest rodzajem komunikacji perswazyjnej - jej funkcją

1 Temat reklamy w służbie teologii poruszają w swoich publikacjach tacy teolodzy jak Andrzej Draguła, Andrzej Zwoliński, Monika Przybysz, Ewa Skwarska czy Monika Sulej.

2 Por. M. Mulle r, T. P o n i kło, Czy dusza może być jeszcze bielsza?, „Tygodnik Powszechny”, 23.11.2008, s. 3. 
jest wywieranie wpływu na wybór, jaki dokonuje konsument"3. W samym akcie perswazyjnym nie ma nic pejoratywnego. Reklama religijna także jest przekazem perswazyjnym, podobnie jak i komunikowanie Kościoła w kaznodziejstwie czy liturgii. Komunikat reklamowy nawiązuje w swojej strukturze do klasycznej retoryki. Posiada bowiem - jak opisuje to dokładnie Piotr H. Lewiński - strukturę mowy retorycznej ${ }^{4}$. Podobnie jest, moim zdaniem, i w reklamie religijnej, choć temat retoryki reklamy religijnej i jego perswazyjny charakter zasługuje na oddzielne opracowanie.

Brak jednoznacznej definicji reklamy religijnej przy jednoczesnym pojawieniu się takich reklam w mediach, czy przestrzeni publicznej, wciąż nie skutkuje badaniami naukowymi nad tego rodzaju reklamą, a nawet trudno znaleźć w obszarze nauk o społeczeństwie, nauk o komunikacji, czy w teologii, definicję reklamy religijnej.

Między innymi dlatego, że jest to swoista „terra incognita” podjąłem się próby zdefiniowania reklamy religijnej a także przeprowadzenia badań naukowych na temat reklamy religijnej w Kościele katolickim i jej recepcji w wybranych grupach społecznych w Polsce. To pierwsze tego rodzaju badania, które zostały poprzedzone refleksją naukową nad reklamą jako pewną formą komunikacji perswazyjnej i których zaledwie niewielki wycinek prezentuję w niniejszym tekście.

Patrząc na pojawiające się w przestrzeni publicznej reklamy religijne i podejmowane coraz częściej w publicystyce zagadnienie reklamy o charakterze religijnym, jak zazwyczaj określają tę reklamę różni autorzy, podjąłem próbę refleksji naukowej dotyczącej komunikacji Kościoła katolickiego z wiernymi, za pomącą tego narzędzia jakim jest reklama5 ${ }^{5}$ A dokładniej, zbadać i opisać fenomen reklamy

3 P.H. L e w i ń s k i, Retoryka reklamy, Wrocław 2008, s. 31.

4 Tamże, s. 70-77.

5 Publicyści chętnie w ostatniej dekadzie sięgają po temat reklamy w Kościele katolickim w takich tygodnikach jak „Wprost”, „Tygodnik Powszechny”, „Gość Niedzielny”. Coraz więcej artykułów można znaleźć także w internecie. 
religijnej, bowiem niewątpliwie jest ona swoistym zjawiskiem w komunikacji między instytucją Kościoła a jego adresatami.

Zastanawiając się, czym jest, albo czym nie jest reklama religijna, i co wyróżnia ją spośród wielu różnych reklam komercyjnych, społecznych czy politycznych, które doczekały się swojej definicji, warto zauważyć, że w znacznym stopniu różni się ona od reklamy komercyjnej - nastawionej na zysk ekonomiczny. Różni się ona także i od pozostałych reklam, społecznej czy politycznej. Reklama społeczna, bowiem to reklama, której głównym celem jest ,wywołanie społecznie pożądanych postaw lub zachowań"6, a reklama polityczna, często określana mianem propagandy, ma za cel poparcie dla takiego, czy innego ugrupowania politycznego, czy jej przedstawiciela?.

Każda z nich jest przekazem o charakterze perswazyjnym. W swojej głównej książce zatytułowanej Marketing Philip Kotler pisze, że „Reklama to wszelkie formy nieosobistej prezentacji i promowania idei, dóbr lub usług przez określonego sponsora"». Papieska Rada do spraw Środków Społecznego Przekazu w dokumencie „Etyka w Reklamie” tak definiuje reklamę: „W ogólnym ujęciu reklama, to po prostu publiczne ogłoszenie, które ma dostarczać informacji i wzbudzać zainteresowanie oraz określoną reakcję" . W dalszej części tego dokumentu czytamy „można wyróżnić wiele typów samej reklamy, takie jak komercyjna reklama produktów i usług, reklama użyteczności publicznej prowadzona na rzecz różnych instytucji, programów

6 D. M a is o n, P. W a s i le w s k i (red.), Propaganda Dobrych Serc, czyli pierwszy tom o Reklamie Społecznej, Kraków 2008, s. 9.

7 Słownik encyklopedyczny tak definiuje reklamę polityczną: Propaganda vel reklama polityczna to świadome oddziaływanie na odbiorcę, jednostkę lub zbiorowość poprzez systematyczne rozpowszechnianie określonych poglądów, idei, haseł za pomocą środków perswazji intelektualnej i emocjonalnej (np. symboli, gestów, słów, skojarzeń), w celu pozyskania zwolenników i nakłonienia ich do zachowań pożądanych z punktu widzenia nadawcy przekazu propagandowego. R. S m o l s k i, M. S m o l s k i, E. H. S t a d t m ü l e r (red.), Stownik encyklopedyczny-Edukacja obywatelska, Wrocław 1999.

8 P. K o t 1 e r, M a r k e t i n g, Poznań 2005, s. 600.

9 Papieska Rada Do Spraw Środków Społecznego Przekazu, Etyka w reklamie, 1997, nr 2. 
i spraw, a także reklama polityczna prowadzona w interesie partii i kandydatów"10. Rada jednak nie definiuje reklamy religijnej, ale w punkcie 8. zaznacza, że „w wielu przypadkach także społeczne instytucje dobroczynne, w tym również wyznaniowe, posługują się reklamą, aby upowszechniać określone treści; mogą to być treści religijne lub patriotyczne, wezwania do tolerancji, współczucia, altruizmu, miłosierdzia wobec potrzebujących; treści dotyczące zdrowia i wychowania, treści konstruktywne i pożyteczne, które wychowują i na wiele sposobów skłaniają ludzi ku dobru"ll.

Tyle i tylko tyle mówią oficjalne dokumenty Kościoła katolickiego o reklamie w ogóle, wyróżniając pewne jej typy (wśród których brakuje reklamy religijnej), czy podając jej funkcje jaką jest informacja, wzbudzenie zainteresowania czy wywołanie odpowiedniej reakcji ze strony jej odbiorcy.

\section{AUTORSKA PRÓBA DEFINICJI REKLAMY RELIGIJNEJ}

Jak zatem zdefiniować reklamę religijną? Pierwszą próbę definicji przedstawiłem w tekście zatytułowanym Religious advertising ${ }^{12}$. Czytamy w nim, że „najbardziej ogólną definicję reklamy religijnej ująć by można w stwierdzeniu; reklama religijna to jeden z elementów marketingu religijnego, danej religii, Kościoła czy wyznania, której celem jest przekazywanie informacji oraz, promocja wartości, idei, i usług o charakterze religijnym, a także kształtowanie postaw i zachowań właściwych dla danej religii, Kościoła czy wyznania. Taka reklama nie jest nastawiona na zysk ekonomiczny. Jest zatem reklamą niekomercyjną. Często utożsamiana jest jednak z reklamą społeczną wykorzystującą różne kanały informacji, w tym środki społecznego przekazu do wywoływania społecznie pożądanych postaw

\footnotetext{
10 Tamże.

11 Tamże, pkt. 8.

12 Zob. K. S t ę p n i a k, Religious advertising, „Warszawskie Studia Pastoralne”, 9(2014) nr 3(24), s. 437-454.
} 
czy zachowań. Jej skuteczność jest niewymierna, trudno bowiem zastosować do niej narzędzia badające skuteczność reklamy"13.

Nas jednak nie będą interesować reklamy religijne w ogólnym tego pojęcia znaczeniu, bowiem reklama religijna informuje o danej religii, Kościele czy wyznaniu oraz promuje wartości, które one głoszą a także usługi o charakterze duszpasterskim. Zatem powinno się mówić o reklamie religijnej w danej religii (na przykład chrześcijańskiej, islamie czy hinduizmie); o reklamie religijnej w Kościele (na przykład, katolickim czy anglikańskim). Każda z nich będzie informowała o danej religii czy danym Kościele, promując jednak czasem różne wartości (choć mogą być one także zbieżne czy podobne), idee i postawy oraz usługi, jakie świadczą one w ramach swojej działalności czy misji, nazywane często posługami religijnymi. Ale nie będzie to nauczanie, przekaz danej doktryny, lecz sposób jej promocji. Można zatem w reklamie religijnej wyróżnić najogólniej reklamę danej religii i reklamę w danym Kościele. I ten podział byłby, moim zdaniem, najbardziej czytelny ${ }^{14}$.

Czym zatem byłaby reklama religijna w Kościele katolickim? Posiłkując się językiem teologii można przyjąć, że reklama religijna w Kościele katolickim to taki przekaz, który wpływa na kształtowanie postaw oraz zachowań charakterystycznych dla osób wierzących w Boga, który objawił się w osobie Jezusa Chrystusa. To przekaz zmierzający do promocji poznania Boga i Jego objawienia, nauczania prawd wiary i moralności właściwych dla Kościoła katolickiego oraz posług religijnych, za pomocą wszelkich infostrad, zawierający pewne elementy sacrum. Taka reklama zawiera w sobie element ewangelizacji czy reewangelizacji, jakim jest osobowe spotkanie z Bogiem i przyjęcie Go przez prawdy objawione w nauczaniu i osobie Jezusa Chrystusa oraz model życia proponowany przez wspólnotę Kościoła do której decydujemy się należeć i z posług (usług), którego

\footnotetext{
13 Tamże, s. 438.
}

14 Zob. tamże. 
chcemy korzystać. Taka reklama jest formą komunikacji współczesnego Kościoła katolickiego z człowiekiem żyjącym tu i teraz ${ }^{15}$.

Reklama religijna w swej funkcji informującej przybliża przekaz Kościoła katolickiego, informować może o samym Kościele, jego posługach czy akcjach np. charytatywnych. W swej funkcji nakłaniającej zaś zachęcać do życia zgodnego z wartościami, które niesie chrześcijaństwo, a które głosi Kościół katolicki oraz nakłaniać do korzystania z posług duszpasterskich.

Jakie są cele reklamy religijnej? W mojej opinii zamknąć je można w następujących punktach:

- Reklama religijna ma za cel uświadomić odbiorcom ich potrzeby duchowe i rozbudzić w nich chęć ich zaspokojenia. Współczesny człowiek, którego nazwać można homo consumens, skupia się na swoich potrzebach zazwyczaj czysto materialnych czy fizycznych. Staje się wiecznym konsumentem dóbr, które wytwarza i które mają czy powinny mu służyć. Często przy tym nie uświadamia sobie w całym zawirowaniu codziennego życia, że są w nim pewne duchowe potrzeby, pewien głód duszy, które także domaga się zaspokojenia.

- Ukazywanie apetibilitas czyli atrakcyjności danej religii. W świecie pełnym multikulturowości i religijnego eklektyzmu łatwo jest zagubić swoją pierwotną religijność i to, co Katechizm Kościoła Katolickiego nazywa Capax Dei, swoją otwartość na Boga ${ }^{16}$. Z całym kalejdoskopie Kościołów, wyznań, religii, reklama religijna ma za cel pokazać atrakcyjność chrześcijaństwa, uniwersalizm nauczania Chrystusa, który objawia nam Boga, a o którym naucza Kościół nieprzerwanie od pierwszych wieków chrześcijaństwa.

- Kreowanie preferencji i dostarczanie argumentów rozumowych za wyborem danej religii czy kościoła. Wiara i nauczanie Jezusa, które pragnie nam przybliżyć Kościół posługując się reklamą jako narzędziem komunikacji czy promocji jest czymś,

15 Tamże.

16 KKK 27. 
co nie stoi w sprzeczności z rozumem, jak chcieliby niektórzy. Argumenty rozumowe, a nie emocjonalne tylko, znajdują się w przekazach reklamowych i trzeba je umieć zarówno zawrzeć w reklamie, jak i je odczytać.

- Kształtowanie pozytywnego wyobrażenia o nadawcy reklamy. Nadawcą reklamy religijnej jest Kościół rozumiany jako pewna i konkretna instytucja. Cała historia Kościoła z wielkimi postaciami świętych, charyzmatycznymi osobowościami, które także pojawiają się w reklamie, kształtuje wyobrażenie odbiorców na temat nadawcy komunikatu reklamowego.

- Zachęcenie do konkretnego działania zgodnego z celem przekazu reklamowego. Reklama powinna w swej warstwie perswazyjnej nakłaniać do konkretnego działania. Działania, które jest zgodne z zamierzeniami twórców-nadawców reklamy.

- Korzystanie z posług. Celem reklamy jest korzystanie z tego, co ona proponuje. Czy jest to zachęta do konsumpcji, czy do korzystania z usług, zawsze jest to konkretne działanie tu i teraz. Reklama religijna, podobnie jak reklama w ogóle, nakłania odbiorcę do pewnych działań. W wśród nich jest korzystanie z posług kapłańskich, z sakramentów, rekolekcji etc.

Ze względu na treść przekazywaną w reklamie religijnej Kościoła katolickiego oraz jej odbiorcę, można wyróżnić następujące typy reklamy religijnej: reklamę kerygmatyczną/ewangelizacyjną, duszpasterską, powołaniową i fundraisingową (dobroczynną).

- Reklama kerygmatyczna/ewangelizacyjna - jej treścią jest kerygmat (prawda o Zbawieniu, które dokonało się w Osobie Jezusa Chrystusa), a jego odbiorcą ci, którzy tego objawienia jeszcze nie znają; lub jej treścią jest Ewangelia i jej nauczanie skierowane do osób należących do Kościoła lub będących na jego obrzeżach, poszukujących w nim swojej drogi życia.

- Reklama duszpasterska - jej treścią są wszelkie inicjatywy duszpasterskie, rekolekcje, akcje prowadzone w parafii, akcje o charakterze ogólnokościelnym, a odbiorcą należący do danej wspólnoty wiernych, choć i inne osoby niezwiązane z Kościołem. 
- Reklama powołaniowa - zachęcająca do wybrania drogi kapłańskiej, zakonnej czy misyjnej. Ale także do różnych zadań w Kościele, które mogą podejmować świeccy.

- Reklama fundraisingowa (dobroczynna) - pozyskująca środki finansowe na działalność Kościoła, odwołująca się do argumentów płynących z wiary.

\section{BADANIA FOCUSOWE DOTYCZACE REKLAMY RELIGIJNEJ}

Oopierając się na przedstawionych powyżej założeniach dotyczących reklamy religijnej i definicje, podjąłem próbę badań empirycznych nad reklamą religijną. Zostały one przeprowadzone w Laboratorium Badań Medioznawczych Uniwersytetu Warszawskiego w okresie luty-maj 2016 roku. Materiał jaki powstał w wyniku 4 dyskusji focusowych stanowi część projektu badawczego dotyczącego roli, oddziaływania i konstrukcji reklamy religijnej. Pełny raport z badań zawiera także analizę narracyjno-semiotyczną prezentowanych w badaniu reklam.

Trzeba podkreślić, że badania focusowe, od strony metodologicznej, to badania jakościowe, które wypracowały swoją własną tożsamość. Mają one na celu bliższe przyjrzenie się „światu zewnętrznemu", a nie sztucznym sytuacjom wytworzonym np. w laboratoriach, oraz opis, interpretację, czy wyjaśnienie zjawisk społecznych z perspektywy „wewnętrznej” poprzez; analizę doświadczenia jednostek i grup; analizę interakcji i aktów komunikacji w czasie ich trwania i analizę dokumentów (tekstów, obrazów, filmów czy muzyki). Tego rodzaju badania oparte na grupach focusowych pojawiły się $\mathrm{w}$ latach czterdziestych ubiegłego wieku ${ }^{17}$. Szybko stały się też filarem badań w dziedzinie mediów, marketingu i public relations.

17 Pierwszymi, którzy zastosowali badania focusowe byli Paul Lazarsfeld i Robert Merton, by zbadać reakcję na propagandę i programy radiowe podczas drugiej wojny światowej. Zob. R. M e r t o n, P. K e n d a 11, The focused interview, "American Journal of Sociology", 51/1946, s. 541-557. 
Grupy focusowe, jak inne metody jakościowe, wyróżniają się tym, że pozwalają raczej na zgłębienie procesu niż samych wyników. Co więcej, w tego rodzaju badaniach nie chodzi o osiągnięcie konsensusu między uczestnikami grupy czy poszczególnymi grupami, ale ważne są pewne procesy zachodzące w grupie, wymiana zadań, a nie sam wynik dyskusji. Uczestnicy badań focusowych często zmieniają zdanie w czasie trwania dyskusji. Można zatem podsumować, że tego rodzaju badania umożliwiają badanie procesów kształtowania się opinii i mechanizmów związanych z kwestionowaniem i zmianą poglądów ${ }^{18}$.

W celu otrzymania szerokiego spectrum poglądów na reklamę religijną w badaniu autorskim, które opisuję, zastosowano taki dobór uczestników grup focusowych, by w badaniu wzięły udział zarówno osoby zajmujące się reklamą, jak i ci, którzy są jedynie jej odbiorcami. Badanie przeprowadzono w 4 grupach.

Pierwsza grupa fokusowa to „Eksperci” - osoby związane z Kościołem i mające kontakt z reklamą religijną oraz medioznawcy zajmujący się reklamą poza kontekstem religijnym.

Druga grupa fokusowa to „Niewierzący” - osoby niepraktykujące i deklarujące brak kontaktu z Kościołem, jednak nie deklarujące otwartej krytyki i wrogości wobec tej instytucji.

Trzecia grupa fokusowa to „Duchowni” - osoby duchowne (zakonnice, diakoni, klerycy).

Czwarta grupa fokusowa to „Wierzący” - osoby deklarujące się jako wierzące i praktykujące.

Wykorzystane w niniejszym tekście wypowiedzi członków wszystkich tych grup oznaczono nazwą grupy w nawiasach kwadratowych i ponumerowano według klucza zastosowanego w badaniu. Wypowiedzi dotyczą jedynie reklam religijnych zaprezentowanych podczas badania, bowiem oprócz dyskusji nad teoretycznymi zagadnieniami czy pytaniami badawczymi zastosowano w badaniu, zgodnie w metodologią badań jakościowych, prezentację wybranych reklam statycznych i reklam wizualnych. Materiał empiryczny został

18 Zob. R. B a r b o u r, Badania focusowe, Warszawa 2011, s. 64-67. 
poddany klasyfikacji i kategoryzacji. Kategorie analityczne obejmowały takie zagadnienia jak:

1. Granica pojęcia i definicja reklamy religijnej;

2. Ocena zjawiska reklamy religijnej - potrzeba i stosowność jej stosowania w kontekście roli i misji Kościoła;

3. Cele i funkcje reklamy religijnej - środki stylistyczne i elementy konstrukcji przekazu reklamowego denotujące odniesienia do sacrum;

4. Rola reklamy religijnej w kształtowaniu duchowości katolickiej, ze szczególnym uwzględnieniem osobowego kontaktu z Bogiem;

5. Pożądane i niepożądane cechy konstrukcji reklam religijnych;

6. Spontanicznie przywoływane przykłady reklam religijnych;

7. Mocne, słabe i charakterystyczne cechy badanych reklam.

To, co nas interesuje, z racji tematu niniejszego tekstu, to pierwsze trzy, spośród siedmiu zagadnień, czyli granica pojęcia i definicja reklamy oraz ocena tego zjawiska, jakim jest reklama religijna w Kościele katolickim, a także elementy sacrum występujące w reklamie religijnej. Prezentowane zagadnienia i wypowiedzi uczestników grup fokusowych są jedynie wycinkiem całego raportu z badań.

\section{GRANICE POJECIA REKLAMY I JEJ OBECNOŚĆ W PRZESTRZENI PUBLICZNEJ}

Zagadnienie dotyczące granic pojęcia reklamy religijnej zostało postawione w formie dosłownej jedynie w grupie ekspertów. W pozostałych grupach, nie pytano o granice pojęcia reklamy lecz o to, z czym kojarzy im się reklama religijna.

- W gronie ekspertów dominowało przekonanie, że reklamę religijną definiuje głównie jej przedmiot.

[Ekspert 1]: Pewnie tutaj musimy się zastanowić nad przedmiotem takiej reklamy, by spróbować wyłonić taką kategorię jaką jest reklama religijna, by także zastanowić się nad jej treściami 
[Ekspert 2]: Trzeba zacząć od tego co miałaby reklamować taka reklama religijna? Czyli od przedmiotu takiej reklamy, bo wydaje mi się, że pojawia się kilkanaście różnych definicji, choć w literaturze przedmiotu takich nie znalazłam? Każdy autor, który coś pisze, ma już swoją definicję reklamy w ogóle. Rodzi się pytanie czy reklama religijna ma reklamować, promować, komunikować jakąś ideę religijną? Czy jakąś konkretną instytucję? To znaczy, chodzi mi dokładnie o zakreślanie podmiotu badania.

[Ekspert 3]: Problem polega na tym, że mamy bardzo nieostre i takie mgliste pojęcie tego, co hasłowo nazywamy reklamą religijną. Bo w gruncie rzeczy jest to konglomerat różnego rodzaju działań. Działań, które byśmy zaklasyfikowali jako właściwe dla mechanizmów reklamy, ale także działań wizerunkowych, działań z zakresu public relations. To są różnego rodzaju działania, których - wydaje mi się wyznacznik formalny jest tutaj nawet bardziej dookreślający niż celowy, znaczy takie działania, które zaprzęgają różnego rodzaju nowoczesne technologie medialne, czy to będą internetowe, czy outdoorowe, czy - chociaż najczęściej to jest właśnie - działania wizualne. (...) tak w dużej mierze, trudniej jest zdefiniować przedmiot i trudniej jest zdefiniować cel, bo przedmiotem nie musi być wyłącznie Bóg, jak to zostało powiedziane, ale mogą być także pewne działania duszpasterskie, czy nawet sama instytucja, czy też pewne działania związane z instytucją

- Niektórzy z ekspertów mieli pewną wątpliwość czy w ogóle można używać pojęcia reklamy religijnej, choć w dalszej części dyskusji w tej grupie pojęcie to było w powszechnym użyciu wśród wszystkich uczestników dyskusji.

[Ekspert 1]: W literaturze anglojęzycznej nie spotkałam takiego pojęcia jak reklama religijna, jeśli już to treści religijnych, to jest pierwsza rzecz. Nie wydziela się tu osobnego działu, jakim byłby dział reklamy religijnej (...) reklama jest nie tylko reklamą produktu konkretnego, materialnego, ale też idei lub usługi, w związku z tym, w tym pojęciu obejmuje jakby treści także religijne.

[Ekspert 4]: Niektórzy wolą na przykład sformułowanie ,promocja wiary”, jako szersze zjawisko, a nie „reklama religijna”. Czyli 
„promocja wiary” zamiast „reklama religijna”, gdzie w promocję wchodzą różne działania

[Ekspert 5]: Myślę, że posługiwanie się pojęciem promocji wiary jednak bardzo nam rozluźnia pole dyskusji, to znaczy jednak samo zjawisko reklamy jest na tyle precyzyjnie dodefiniowane, że wiemy, że to musi się odbywać określonego rodzaju kanałem komunikacji etc. etc. Promocja wiary to odrębny temat znacznie szerszy zakresowo od reklamy.

- Grupa ekspertów podjęła także w dyskusji problem pejoratywnych konotacji związanych z pojęciem reklamy religijnej

[Ekspert 3]: A myślę, że przede wszystkim uciekamy od konotacji, nie marketingowych, a rynkowych, że reklama jednak kojarzy nam się nieustanie z reklamą komercyjną, a nie jest reklamą społeczną, w związku z tym, boimy się takiego skojarzenia wiary z reklamą rozumianą jako czynności zmierzające w gruncie rzeczy do sprzedaży.

[Ekspert 6]: Jeśli odróżniamy wiarę i religię, jako wiarę osobową, która nie ma wymiaru instytucjonalnego, to za tym może iść przekonanie, że wiary nie da się reklamować. Ale jest to trochę idealistyczne. Wiemy bowiem, że się da reklamować wiarę przypomina mi się świetne hasło, niby-reklamowe, pielgrzymki Benedykta XVI do Niemiec, „Człowiek nigdy nie jest sam”. W sposób oczywisty jest to przepiękna reklama wiary właśnie w kontekście eventu, że przyjeżdża Papież. Czyli wiarę też da się jakoś reklamować.

- Reklama religijna jest medium, które prowadzić ma do osobowego kontaktu z Bogiem

[Ekspert 3]: Na pewno te dwa wyrazy określają, czy naprowadzają odbiorcę na rozumienie tego zjawiska, czy tej treści, które się kryją za tymi wyrazami, czyli „reklama religijna”. „Reklama”, czyli coś rozgłaszam, powtórnie ogłaszam, powtórnie komunikuję, powtórnie o czymś krzyczę. A z drugiej strony „religijna”, „religia”, to coś, co łączy, tak? Mamy przekonanie, że chodzi o „łączenie” z Absolutem, chodzi o „łączenie” z Bogiem. Czyli to reklama ukierunkowująca człowieka na Boga.

[Ekspert 7]: Ta reklama łączy z Bogiem przez pewien wymiar estetyczny. Nawet mówimy dzisiaj, że ona jest w sferze sztuki, że 
to nie jest tylko kwestia informacji, ale że ona jest sama w sobie sztuką. No jeśli przyjmiemy istnienie Boga jako realne, a nie tylko jako artefakt, który próbujemy tu połączyć w szereg innych reklam, też komercyjnych, przyjmując jego realne istnienie, to możemy też założyć coś takiego, że Pan Bóg może wykorzystać piękne, genialne dzieło do inspiracji każdego.

- Reklama religijna kształtuje także postawy odbiorców

[Ekspert 2]: Reklama religijna przez to między innymi, że zachęca się do udziału w jakimkolwiek rodzaju wydarzeniach, technikami, które temu służą, kształtuje postawy, czyli dostarcza wiedzy, wywołuje emocje i angażuje... taka jest też idea perswazyjności reklamy, natomiast treści mogą być różne, treści sakralne oczywiście także.

Pozostałe grupy nie dyskutowały na temat granic pojęcia reklamy religijnej i tego, co stanowi jej przedmiot czy cel. Postawiono im pytanie dotyczące obecności reklamy religijnej i jej miejsca w otaczającym ich świecie. Czy taka reklama jest w ogóle potrzebna?

[Niewierzący 1]: Tylko chleb nie potrzebuje reklamy, a i tak jest reklama chleba.

[Duchowny 1]: Myślę, że Kościół potrzebuje reklamy i de facto się reklamuje. To jest stan faktyczny, jeżeli zobaczymy, nie wiem, duże akcje ewangelizacyjne, które są de facto pewną formą reklamy albo jak zobaczymy, jak Kościół pokazuje się poprzez duże kampanie, akcje, billboardy, widzimy, że Kościół stara się reklamować. Może nie tyle pytanie czy, ale w jaki sposób.

[Duchowny 2]: Moim zdaniem, w Kościele trzeba się zastanowić co chcemy reklamować, bo nie jestem zwolennikiem, że wszystko trzeba reklamować. Natomiast, czy reklama jest potrzeba? Ona jest potrzebna, potrzebna przede wszystkim jako aspekt promocyjny, ale i informacyjny. Prosta sprawa, jeżeli mam w parafii jakąś gazetkę, a nie powiem o tym w ogłoszeniach, to nikt tego nie kupi. Od razu wzrasta sprzedaż. To samo w telewizji. Jakiś głupi śmieć nawet wymyślą i zareklamują, to ludzie to kupią. Dlaczego zatem nie reklamować tego, co ma wielką wartość, czyli religię, wiarę... 
- Reklama religijna to jest pewien rodzaj reklamy, który jest przez wszystkich uczestników grup - poza ekspercką- czymś akceptowalnym. To pewien typ reklamy.

[Wierzący 1]: Ja nie widzę tu żadnego problemu, czy takie reklamy powinny być obecne w przestrzeni publicznej. One po prostu są. Jak jedzie się przez Niemcy, spotyka się wielkie reklamy „Ich Liebe Dich. Got", które wiszą przy autostradzie A1. I one są potężne, widać je $\mathrm{z}$ daleka i nie przypominam sobie, nie znam nawet, w relacjach medialnych, żadnego oporu wobec tych reklam... ze względu właśnie na wolność religijną. Być może dzisiaj reklama „Ich Liebe Dich. Allach”, wywoływałaby jakieś napięcia, ale napięcia bardziej wynikające nie tyle z natury religii co społeczno-politycznych kontekstów tych religii, tak, że sam fakt nie budzi we mnie zastrzeżeń, zwłaszcza że dzisiaj mamy wiele reklam antyreligijnych czy ateistycznych, które funkcjonują bardzo dobrze w przestrzeni publicznej i nikt z tego powodu, z osób wierzących, chyba nie zgłasza wątpliwości, bo ta przestrzeń jest współdzielona.

[Wierzący 2]: Wracając do tego pytania, czym jest właściwe reklamowanie Boga, to ja w ogóle nie widzę z tym żadnego problemu i nie traktuję tutaj idei Boga jako czegoś komercyjnego. Bóg nie staje się produktem, natomiast tak samo jak mamy reklamy społeczne na przykład, tak samo możemy promować ideę wiary, możemy promować Boga, jako takiego, oczywiście jedną stroną idą sobie rzeczy związane z reklamowaniem na przykład eventu jakiegoś, powiedzmy kościelnego... Jakiegoś wydarzenia, jakiejś usługi kapłańskiej - różne rzeczy tutaj możemy wskazać - ale z drugiej strony może być ten meta poziom, w którym pokazujemy Boga, jako pewną ideę, którą chcemy promować, nie widzę tu żadnego problemu. Tym bardziej, że, z drugiej strony, mamy szereg działań już komercyjnych, ale i niekomercyjnych, bazujących na show advertising, bazujących na promocji idei przeciwnych Bogu. Więc dlaczego nie zachowywać takiej równowagi i dlaczego się obawiać prewencyjnie jakiejś złej opinii. Nie widzę w tym żadnego problemu, uważam, że współczesna komunikacja marketingowa jest dostępna dla wszystkich, dla każdej instytucji i jeżeli Kościół nie będzie podejmował odpowiednich, 
skutecznych działań komunikacyjnych, nowoczesnych, no to będzie musiał liczyć się z tym, że szczególnie młodzi będą oddalali się od niego.

Dyskusja w grupach focusowych pokazała, że reklama religijna jest powszechnie używanym pojęciem i odnosi się jedynie do reklamy, której treść ma wyraźne przesłanie religijne. Najwięcej wątpliwości rodziło się w gronie ekspertów, którzy uważają, że wciąż pojęcie reklamy religijnej jest niedookreślone czy mylone w marketingiem religijnym. Tu podkreślić trzeba, że reklama religijna jest częścią działań promocyjnych, a promocja należy do marketingu, stąd czasem mylne łączenie reklamy religijnej z marketingiem religijnym. Reklama religijna może, zdaniem badanych, kształtować postawy odbiorców i prowadzić do refleksji o charakterze religijnym, a nawet być narzędziem nowej ewangelizacji. Żyjemy dziś w epoce obrazu, w ikonosferze, stąd zdaniem wielu badanych, konieczność sięgania po tego rodzaju narzędzia jak reklama religijna. Tego wymaga współczesny odbiorca.

\section{ELEMENTY SACRUM W REKLAMIE RELIGIJNEJ}

W trakcie trwania dyskusji pojawiło się pojęcie sacrum w reklamie religijnej. Używając pojęcia sacrum mam na myśli nie pewne elementy religijne czy odwołania do religii chrześcijańskiej, po które często sięga reklama komercyjna ${ }^{19}$. Sacrum w reklamie religijnej - inaczej niż w komercyjnej, rynkowej - posiada pewien związek referencyjny z religią. Termin ten oznacza coś tajemniczego i transcendentnego, pełnego świętości i nadprzyrodzoności, i zupełnie przeciwnego profanum. Podział ten wypływa przede wszystkim z fenomenologicznego patrzenia na sacrum. Szkoła fenomenologiczna z takimi przedstawicielami jak Rudolf Otto, Gerard van der Leeuw i Mircea Eliade pogłębiła refleksję nad pojęciem sacrum francuskiej szkoły socjologicznej, której przedstawicielami byli Henri Hubert, Marcel Mauss i Émile Durkheim.

19 A. Tu r e k, Sacrum na sprzedaż, Lublin 2002. 
Rudolf Otto, Gerard van der Leeuw i Mircea Eliade pisali w swoich pracach o tym, co stanowi wspólną rzeczywistość dla wszystkich religii i określali to mianem sacrum, choć nieco inaczej je pojmowali.

R. Otto ${ }^{20}$ twierdził, że człowiek posiada w głębi swojego jestestwa realne przeczucie istnienia wyższego bytu. Jest to przeczucie, którego istotą jest aprioryczne przeczucie przez człowieka rzeczywistości sakralnej. Przeczucie to nie ma nic wspólnego ze sferą emocjonalną człowieka czy uczuciową. Jest to nagłe stawanie człowieka wobec rzeczywistości zupełnie odmiennej, intuicyjnej i bezpośredniej. Istota tego doświadczenia przekracza pojęciowe możliwości poznania ludzkiego ${ }^{21}$. Zdefiniowanie sacrum jest, według R. Otto, niemożliwe. Człowiek doświadcza pewnej rzeczywistości sakralnej, przeżywa ją. Wśród tych przeżyć na szczególną uwagę zasługują najbardziej charakterystyczne czyli mysterium tremendum, fascinosum i augustum. Mysterium tremendum polega na tym, że człowiek doświadczając sacrum doznaje uczucia grozy i lęku, który wynika z tajemniczości, majestatu i potęgi sakralnej. W obliczu sacrum człowiek uświadamia sobie swoją nicość i odczuwa strach ${ }^{22}$.

Mysterium tremendum i fascinosum, które przeżywa człowiek sprawia, że rzeczywistość sacrum z jednej strony go przeraża i napełnia lękiem, z drugiej zaś pociąga i fascynuje, a tym samym zobowiązuje sumienie do postępowania zgodnego z moralnymi zasadami, które wynikają z tego doświadczenia. I tu pojawia się termin: augustum, który odnosi się do systemu wartości. Doświadczenie sacrum stanowi najgłębsze źródło wszelkiej moralności, pozwala odróżnić dobro od

20 Rudolf Otto (1869-1937) - niemiecki religioznawca, filozof i teolog. Wykładowca teologii systematycznej na Uniwersytecie w Getyndze, od 1917 profesor teologii i historii religii na Uniwersytecie w Marburgu. Założyciel organizacji Religiöser Menschheitsbund, której celem była współpraca etyczna ludzi reprezentujących różne przekonania religijne.

${ }_{21}$ Por. R. O t t o, Świętość. Elementy irracjonalne w pojęciu bóstwa i ich stosunek do elementów racjonalnych, (tłum.) B. Kupis, Warszawa 1968, s. 38-40.

22 Tenże, s. 181. Zob. także H.W. S c h u t t e, Religion und Christentum in der Theologie Rudolf Otto, Berlin 1969, 34nn. 
zła i odkryć takie wartości jak piękno, dobro, sprawiedliwośćc 23 . Sacrum jest wartością samoistną, obiektywną, nieskończoną, będącą irracjonalną podstawą i źródłem wszelkich wartości np. dobra, piękna a nie ich sumą.

G. Van der Leeuw ${ }^{24} \mathrm{z}$ kolei zauważa, że człowiek ze swej natury dąży do zrozumienia sensu życia i określa to wolą mocy. Ta wola mocy pozwala odkryć moc, która nadałaby ludzkiemu życiu głębszy sens. Człowiek nie akceptuje danego mu życia, lecz wciąż pragnie życia bogatszego, pełnego sensu i zrozumienia. Te poszukiwania sprawiają, że porządkuje on i organizuje życie w sensowną całość, tworząc w ten sposób kulturę. Jednak jego poszukiwania mocy i sensu trwają nadal i wreszcie dochodzi człowiek do pytania o sens ostateczny swojego życia i otaczającego go świata. Wówczas odkrywa religijny wymiar rzeczywistości, który nadaje wszystkiemu najgłębszy, całościowy, ostateczny sens ${ }^{25}$.

Pojęcie mocy oznacza rzeczywistość sakralną o absolutnym charakterze, która jest źródłem zjawiska jakim jest religia. Moc jako taka nie jest dostępna ludzkiemu poznaniu, jednak można uchwycić jej historyczną formę czyli historyczne systemy religijne.

Jeszcze inaczej opisuje sacrum Mircea Eliade ${ }^{26}$, opisuje, a nie definiuje, bowiem określa je za pomocą opozycji czy przeciwstawienia

23 Por. M a r k ow s k i, Fenomenologiczne interpretacje pojecia sacrum, „Warszawskie Studia Teologiczne”, 23(20120) nr 2, s. 73-74.

24 Gerard van der Leeuw (1890-1950) - holenderski religioznawca, który dokonał opracowania metodologicznego statusu fenomenologii religii. W 1918 roku został powołany na katedrę historii religii Uniwersytetu w Groningen i stanowisko to piastował do swojej śmierci. Współzałożyciel i prezes Holenderskiego Towarzystwa Religioznawczego oraz współinicjator i prezes International Association for the Study of the History of Religions.

25 R. Markowski, Fenomenologiczne interpretacje pojęcia sacrum, art. cyt., s. 75.

26 Mircea Eliade (1907-1986) - rumuński religioznawca, od 1933 roku wykładowca na Uniwersytecie w Bukareszcie. Po drugiej wojnie światowej w 1945 roku osiedlił się w Paryżu, gdzie na przełomie 1947/1948 w Ecôle des Hautes Etudes wygłosił serię prelekcji na temat struktury sacrum i mitu. W 1956 wyjechał do Stanów Zjednoczonych, gdzie został wykładowcą Uniwersytetu w Chicago, zaś w 1957 roku na tymże Uniwersytecie objął katedrę historii religii, którą kierował do swojej śmierci. 
wobec profanum i podejmuje próbę ustalenia zakresu znaczeniowego tych dwóch kategorii, sacrum i profanum. W Traktacie o historii religii M. Eliadego czytamy, że sacrum jest całkowicie odmienne od profanum i stanowi inny rodzaj rzeczywistości. Sacrum utożsamia on z tym co realne, rzeczywiste i ponadhistoryczne, profanum zaś oznacza sferę tego co nierealne, przypadkowe i ściśle związane ze zmieniającymi się dziejami świata. Sacrum wskazuje więc na byt prawdziwy i niezmienny, profanum na byt przygodny, istniejący w sposób wtórny. Jednocześnie, te tak diametralnie różne rzeczywistości, są dla siebie niezbędne, zachodzi między nimi swoista dialektyka i zależność. Otóż sacrum, czyli to, co nieskończone i ahistoryczne, zawsze manifestuje swoją obecność poprzez profanum, czyli to, co skończone i historyczne ${ }^{27}$.

Sacrum jako rzeczywistość nigdy nie jest dana człowiekowi wprost, bezpośrednio. Manifestuje się przez sferę profanum i tę manifestację Eliade określa mianem hierofanii. W swoich badaniach Eliade podkreśla, że swoista dialektyka zachodząca między sacrum a profanum sprawia, że w hierofaniach następuje zbieżność tego, co wieczne, i tego, co przemijające. Hierofania jest więc pewnym paradoksem, bowiem jakiś element rzeczywistości empirycznej, pozostając sobą, objawia coś całkiem innego. W każdej hierofanii ukazane jest współistnienie dwóch przeciwstawnych sobie rzeczywistości - ducha i materii, wieczności i doczesności ${ }^{28}$.

Przedstawione uczestnikom grup focusowych reklamy statyczne (plakaty) i dynamiczne cechował pewien element sacrum. Owo sacrum przeciwstawione było profanum i można je było poddać pewnej typologizacji ze świadomością, że nie jest ona ani zbiorem zamkniętym, ani kompletnym. To, co stanowi element sacrum, ująć można w pewne kategorie:

1. kategorie podstawowe jak: ryty celebrowane przez kapłana, odwołania do Pisma Świętego i doktryny nauczania Kościoła, apokryfy i legendy kościelne, żywoty świętych, symbole

27 Por. M. E1 i a d e, Traktat o historii religii, (tłum.) J. Wierusz-Kowalski, Warszawa 1966, s. 20-28.

28 R. M a r k ow s k i, Fenomenologiczne interpretacje..., art. cyt., s.78. 
religijne, postacie świętych, błogosławionych (bohaterowie religijni), osoby duchowne, cytaty, i odwołania do historii Kościoła jako historii pewnej instytucji;

2. estetyka religijna; ikonografia, muzyka, która nie jest częścią rytu religijnego, stroje, architektura i rzemiosło;

3. etyka i wartości, czy moralność płynąca z Biblii, ale także wartości uniwersalne czy też historyczne przykłady działań zgodnych z wartościami chrześcijańskimi;

4. styl życia, czyli praktyki religijne i świadectwo życia tych, którzy należą do wspólnoty Kościoła, oraz styl życia duchownych. To takie elementy jak ryty osobiste, jako element budowy tożsamości jednostek, oraz ryty budujące tożsamość grupy czy konstytuujące jakieś wspólnoty.

Często na określenie sacrum w reklamie uczestnicy grup focusowych nie znajdowali jednoznacznego określenia, często wskazywali na użyte środki stylistyczne czy pewne elementy konstrukcji przekazu reklamowego denotujące odniesienia do sacrum.

- Sacrum, to coś uświęcone, wzniosłe, ekskluzywne, niedostępne dla każdego, coś co jednoznacznie kojarzy się z czymś transcendentnym, mimo że jest rzeczywistością tu i teraz.

[Wierzący 1]: Sacrum to kościół, wnętrze kościoła... takie dostojne, poważne. Chrystus ukrzyżowany i słowa z Pisma Świętego. Cały plakat jest taki natchniony.

[Ekspert 2]: Dla mnie cała ta reklama-kolory, przekaz jest mocno duchowy.

[Niewierzący 1]: Patrząc na billboard mówiący o kanonizacji Jana Pawła II skupiam się nie na obrazie... to nie on jest dla mnie najważniejszy, tylko ten tekst „Idź pod prąd”.

- Sacrum w reklamie religijnej wywołuje pewne emocje, skłania do refleksji, pobudza.

[Ekspert 2]: Na pewno w sferze emocjonalnej, bo ta reklama jest rzeczywiście bardzo refleksyjna, prawda? Jak każda metafora może być czytana na kilku poziomach i dosłownych, gdzie jest trafna, prawda? I rzeczywiście na takim poziomie kilku przenośni moglibyśmy to czytać, więc samo to jest bardzo ładne, duchowe... 
[Wierzący 1]: Pomysł, by Dekalog ująć w formie billboardów mimo jakiś tam wad, jest dla mnie doskonałym pomysłem. Poza tym bardzo mi się podoba, ale to już czysto emocjonalnie... wreszcie jest przekaz „Kocham Cię”, „Bóg jest miłością”.

- Sacrum to coś zamkniętego w pewnej symbolice, środkach wyrazu, znaku czy linii kolorystycznej lub muzyce

[Duchowny 1]: Sama muzyka w tej reklamie buduje obraz. Gdyby nawet nie było obrazu, to sama muzyka rzeczywiście wskazuje na coś z dziedziny sacrum. Jest więc intrygująca, wciąga...

[Niewierzący 2]: Ta reklama budzi we mnie pewne skojarzenia: piekielny ogień, czerwone gotyckie napisy, i ten końcowy napis jak z reklamy jednej sieci sklepów „,nie dla idiotów”... postaci rycerzy średniowiecza, to znaczy Kościół katolicki nie dla tchórzy.

- A także pewne napięcie między sacrum a profanum, przeciwstawienie tych dwóch elementów na pewnych osiach: świętość i grzeszność, kapłaństwo i świeckość; refleksja i pośpiech, wartości a etykiety, pozory; postawy i motywacje kontra pokusy i popędy.

[Wierzący 1]: Reklama powołaniowa, to jest ten rodzaj reklamy, który pokazuje pewne przeciwieństwo do tego, co dziś lansuje świat. Ja odbieram tych młodych duchownych jako bohaterów. I rzeczywiście jest w kościele głód osób świeckich na kapłana. I to pokazanie duchownego i wyniesienie go do rangi bohatera, który rzeczywiście podniesie $\mathrm{z}$ upadku, poda dłoń, wesprze gdy jesteśmy słabi jest ogromnie duchowe.

[Duchowny 1]: Te wszystkie elementy męstwa, honoru, rycerskości to pokazuje jaki jest dziś Kościół. Tu toczy się prawdziwa walka o ludzkie dusze. To uderza w tej reklamie, jest w niej wiele emocji. Tu są hasła: wiara, modlitwa, męstwo, walka duchowa. To jest moja wewnętrzna postawa, mam podjąć pewną walkę, jak rycerz...

Warto także rozróżnić pozytywny, skuteczny z punktu widzenia perswazyjnego sposób użycia danego symbolu czy środka stylistycznego w reklamie, od kontekstu negatywnego, zaburzającego odbiór treści religijnych. 


\section{ZAKOŃCZENIE}

Reklama religijna jest pewnym fenomenem w otaczającej nas rzeczywistości. To zjawisko, które jest obecne w przestrzeni publicznej nie tylko na ulicach wielkich miast czy autostrad. Towarzyszy nam w środkach komunikacji miejskiej, na przystankach, w metrze czy na przydrożnych billboardach. Czasem intryguje, pobudza do refleksji, a czasem nawet szokuje.

Tekst, który zaprezentowałem, nie zawiera podstawowych zagadnień badawczych i nie ukazuje reklamy religijnej w kontekście badań nad reklamą czy teorią komunikacji. Jest jedynie próbą zdefiniowania i sklasyfikowania tego zjawiska, jakim jest reklama religijna. Zapewne próba klasyfikacji reklamy religijnej zaproponowana w tekście, jak i definicje mogą budzić pewne wątpliwości czy pobudzać do dyskusji, której mam wrażenie brak w Kościele katolickim, kaznodziejstwie czy teologii.

Pierwsza część artykułu jest częścią większego tekstu na temat reklamy religijnej i stanowi punkt wyjścia do zaprezentowanych jedynie po części - badań empirycznych. Można mieć także nadzieję, że stanie się także okazją do dyskusji czy polemiki na temat reklamy religijnej, bowiem jak pokazały badania przeprowadzone w Polsce, temat budzi wiele emocji czy nawet kontrowersji.

\section{Religious advertising as a persuasive message with elements of the sacrum Summary}

Religious advertising is a particular phenomenon in the reality surrounding us. It is becoming more and more a tool of communication of the Catholic Church used for various purposes; Pastoral, vocation or evangelization. It is often associated with social advertising, although it is not a type of social advertising. It is a type of persuasive message that contains elements of the sacrum, which distinguishes it from other types of ads.

In this text, the author presents his own definition of religious advertising, its types and defines its purpose. He also presents a slice of focus studies on the 
phenomenon of religious advertising and its reception in selected groups in Poland, conducted in 2016. The presentation of own research deals with the problems and doubts that the concept of religious advertising carries, the description of the phenomenon itself, and focuses on the sacrum as the constitutive element of this type of medium.

Słowa kluczowe: reklama religijna, reklama ewangelizacyjna reklama kerygmatyczna, reklama duszpasterska, reklama powołaniowa, reklama fundraisingowa komunikacja perswazyjna, sacrum.

Key words: Religious advertising, evangelistic advertising, kerygmatic advertising, pastoral advertising, vocation advertising, fundraising advertising, persuasive communication, sacrum.

Nota o autorze: Ks. dr. Krzysztof Stępniak - Dziekan Wydziału Socjologii Akademii Humanistycznej im. Aleksandra Gieysztora w Pułtusku, Wieloletni dyrektor Radia Plus Ciechanów a potem Katolickiego Radia Ciechanów. Obecnie prowadzi zajęcia z komunikacji społecznej, komunikacji medialnej i interpersonalnej. Interesuje się reklamą religijną i jej recepcją w wybranych grupach społecznych. Autor takich artykułów jak „W podwójnej sieci. Reklama czy sposób werbowania czyli sekty w Internecie”, „Internet czy współczesna wieża Babel”, „E-młodzież. Nowe media a styl życia młodzieży” „Reklama religijna”.

\section{Bibliografia:}

Barbour R., Badania focusowe, Warszawa 2011.

Eliade M., Traktat o historii religii, (tłum.) J. Wierusz-Kowalski, Warszawa 1966. Katechizm Kościoła Katolickiego, Poznań 1997.

Kotler Ph., Marketing, Poznań 2005.

Lewiński P. H., Retoryka reklamy, Wrocław 2008,

Maison D., P. Wasilewski (red), Propaganda Dobrych Serc, czyli pierwszy tom o Reklamie Społecznej, Kraków 2008.

Markowski R., Fenomenologiczne interpretacje pojęcia sacrum, „Warszawskie Studia Teologiczne, 23(2010) nr 2, s. 71-80.

Merton R, Kendall P., The focused interview, "American Journal of Sociology", 51/1946, s. 541-557.

Muller M., Ponikło T., Czy dusza może byćjeszcze bielsza?, „Tygodnik Powszechny”, 23.11.2008, s. 3-4. 
Otto R., Świętość. Elementy irracjonalne w pojęciu bóstwa i ich stosunek do elementów racjonalnych, (tłum.) B. Kupis, Warszawa 1968.

Papieska Rada do Spraw Środków Społecznego Przekazu, Etyka w reklamie, 1997. Schutte H. W., Religion und Christentum in der Theologie Rudolf Otto, Berlin 1969. Smolski R., Smolski M., Stadtmüler E. H., (red.), Słownik encyklopedyczny-Edukacja obywatelska, Wrocław 1999.

Stępniak K., Religious advertising, „Warszawskie Studia Pastoralne”, 9(2014) nr 3(24), s. 437-454.

Turek A., Sacrum na sprzedaz, Lublin 2002.

Van der Leeuw G, Fenomenologia religii, (tłum.) J. Prokopiuk, Warszawa 1978. 